\title{
Relationship between particular dendrobiometrical indicators of natural European beech (Fagus sylvatica L.) dendrocenoses in Central Balkan Range
}

\author{
Angel Ferezliev* \\ Experimental Station on Coniferous Forests - Forest Research Institute, Bulgarian Academy of Sciences, 44 \\ Khan Asparuh Blvd., 4600, Velingrad, Bulgaria
}

\begin{abstract}
FEREZLIEV, A., 2017. Relationship between particular dendrobiometrical indicators of natural European beech (Fagus sylvatica L.) dendrocenoses in Central Balkan Range. Folia Oecologica, 44: 69-77.

In parallel studies, different regression models were tested to identify relationships between particular dendrobiometrical indicators on two sample plots representing forests dominated by the European beech in the Central Balkan Range (Bulgaria). The presence of incomplete multicollinearity was studied through correlation matrix for factor variables. To avoid multicollinear negative impact, step multiple regression was applied and adequate regression equations of the relationships under consideration were formulated. The results of statistical analysis confirmed that the link between the investigated indicators is strong and that the 'cloud" data show some 'sphericity' and distribution close to normal. In one of the sample plots, one major volumeforming factor - height does not participate in the obtained regression equation, so it is not possible to estimate its influence. By testing linear and several nonlinear regression dependencies and by mediating widely used statistical criterions for model selection, the optimal linear model of the considered link was chosen.
\end{abstract}

\section{Keywords}

beech forests, height and length of tree crowns, mean diameter, stand parameters

\section{Introduction}

Beech forests are among the most widely spread forests in Bulgaria (TONCHEV et al., 2012). They occupy 17\% of the total forested area of the country (VASILEVA and STIPCOV, 2012) and their yield is $24 \%$ of the total stock (data from the Executive Environment Agency). In addition to their regional importance, there is a vital fact that only the Central Balkan Range comprises around $7 \%$ of the natural beech forests in Bulgaria (CBNPMP 2001-2010, 2001).

All this determine the significance of these forests and the need for detailed study.

The growth and productivity of common beech has been investigated, among others, through differ- ent inventory indicators. For these indicators, numerous authors in Bulgaria and Europe carried out studies, determined relationships and suggested various regression models to fit their mutual relationships. The most similar to the issue discussed in this study are the works of Dimitrov and Lazarov (1979), MiHOV and LAZARov (1979), TsaKov et al. (2003), Kramer (1982), BARTELINK (1997), KindERMANN (1998), ForSTREUTER (1999), GUERICKE (2001), WidLOWSKI et al. (2003).

As a part of the same global target, ZHIYANSKI et al. (2014) carried out an analogous investigation in a different region with Scots pine plantations in the Western Rhodopes in Bulgaria. These authors determined the influence of $\mathrm{DBH}$, height, length and crown diameter on the stock in plantations, through multiple regression.

*Corresponding author: e-mail: obig@abv.bg 
To the best of our knowledge, the implementing of this investigation approach and methodology in natural beech stands has not been carried out reported so far.

The aim of the present study was to test and implement regression models describing relationships between particular aboveground biometrical indicators, such as the diameter at breast height $(\mathrm{DBH})$, stand height $(\mathrm{H})$, length of crown $\left(\mathrm{L}_{\mathrm{k}}\right)$, and aboveground stand volume (V), as a part of the study 'Carbon stocks in components of natural European beech ecosystems after thining activities in Central Balkan' (NAYDENOvA et al., 2015), in connection with the project 'Land-use and management impacts on carbon sequestration in mountain ecosystems'.

\section{Materials and methods}

The research ran on two sample plots established within the range of the State Forest Enterprise 'Troyan', located in the Central Balkan Range (Bulgaria). The plots are grown with natural forest stands dominated by European beech (each with an area of 0.1 ha). They have the same characteristics (Table 1), which allowed to perform comparative analyses. The first sample plot (SP1) was used as a control - without human activity, and the second plot (SP2) was characterized with thinning activities conducted 20 years ago (before thinning, the stand density on both plots was the same).

Table 1. Characteristics of experimental plots

\begin{tabular}{cccccccc}
\hline $\begin{array}{c}\text { Sample } \\
\text { plot }\end{array}$ & $\begin{array}{c}\text { Tree species, } \\
\text { age (in 2014) }\end{array}$ & $\begin{array}{c}\text { Slope } \\
\left({ }^{\circ}\right)\end{array}$ & Exposure & $\begin{array}{c}\text { Altitude } \\
(\mathrm{m} \text { asl })\end{array}$ & Geology & $\begin{array}{c}\text { Soil type } \\
\text { (WRB 2014) }\end{array}$ & $\begin{array}{c}\text { Studied } \\
\text { trees }\end{array}$ \\
\hline SP1 & $\begin{array}{c}\text { F. sylvatica } \\
64\end{array}$ & 12.7 & NE & 1,250 & Shales & $\begin{array}{c}\text { Dystric } \\
\text { Cambisols }\end{array}$ & 66 \\
SP2 & $\begin{array}{c}\text { F. sylvatica } \\
64\end{array}$ & 13.7 & NE & 1,300 & & & 618 \\
\hline
\end{tabular}

The studied region of Central Balkan Range is characterized with a temperate continental climate. The average annual temperature is $7^{\circ} \mathrm{C}$. The average monthly temperature ranges from $-3.5^{\circ} \mathrm{C}$ (January) to $22^{\circ} \mathrm{C}$ (July), CBNPMP 2001-2010, 2001. The average annual precipitation amount is $901 \mathrm{~mm}$ and varies between $680 \mathrm{~mm}$ and $1,000 \mathrm{~mm}$, as its quantity and distribution depends both on altitude and on slope exposure. The maximum precipitation level is in summer (June) and the minimum in winter (February). The data on precipitation level for the period from 1972 to 2012 for the region of Beklemeto, Central Balkan Range were gathered from the database of the National Institute of Meteorology and Hydrology - Bulgarian Academy of Sciences (NIMH, 2017). Dendrometrical and biometrical indicators were determined by in situ measurements. Tree $\mathrm{H}$, the height at the beginning of the crown (with ultrasonic altimeter Vertex IV) and DBH of all trees were measured. The mean diameter $\left(\mathrm{DBH}_{\mathrm{m}}\right)$ was determined by the arithmetic basal area. The average height $\left(H_{\mathrm{m}}\right)$ was calculated as the weighted average in terms of basal areas of Lorey's formula. The average length of the crown $\left(\mathrm{L}_{\mathrm{rm}}\right)$ is the arithmetic mean of crowns' diameters (the wider part) of all trees. Stem volume was determined according to the following equation:

$$
\mathrm{V}=g_{1.30} \cdot H \cdot f_{1.30,} \mathrm{~m}^{3} \text {, }
$$

where $\mathrm{f}_{1.30}$ is a tree form factor - specific for each tree species, directly used from a compiled table for species heights for high productive beech (EvANGELOV et al., 2004), $\mathrm{g}_{1.30}$ is basal area $\left(\mathrm{m}^{2}\right)$, and $\mathrm{H}$ is the tree height (m).
The volume of the branches is determined by extrapolating the percentage of branches relative to the stem volume (Sirakov and Duhovnikov, 2004). The total volume of the aboveground stem with branches is defined as the sum of the volumes of all stems and branches.

Stand productivity class was determined from Tables for determining the productivity class for high productive beech trees (NEDYALKOV, 2004).

Multivariable linear regression was applied to investigate the influence of DBH, $\mathrm{H}$ and $\mathrm{L}_{\mathrm{k}}$ on the aboveground volume from the following type:

$$
\mathrm{V}=\mathrm{b}_{0}+\mathrm{b}_{1} \cdot D B H+\mathrm{b}_{2} \cdot H+\mathrm{b}_{3} \cdot L_{k}, \mathrm{~m}^{3}
$$

where $\mathrm{b}_{0}$ is regression coefficient (a free member in the regression equation) and $b_{1}, b_{2}, b_{3}$ are regression coefficients of factor variables.

The presence of multicollinearity was studied through correlation matrix for factor variables $(\mathrm{DBH}, \mathrm{H}$ and $\mathrm{L}_{\mathrm{K}}$ ). To avoid the negative impact of multicollinearity a stepwise multiple regression was applied.

For establishing the connection between the aboveground volume and stand height, one linear and six non-linear regressions (quadratic, cubic, power, inverse (hyperbolic), exponential and logarithmic) were tested in one of the two studied plots. The regression analysis was performed using the software product SPSS.

The optimal of the studied models was selected after their evaluation using the criteria for model choice Akaike (AIC) (AKAIKE, 1974; KULLBACK and LEIBLER, 1951), Bayesian (BIC), SchwARz (1978) and root- 
means-square deviation (RMSD), MYUNG (2000). We used AIC, BIC and RMSD, with the following formulae:

$$
A I C=-2 \log (L)+2 k,
$$

where $\mathrm{k}$ is the number of parameters in the model, and $\mathrm{L}$ is maximum probability function for the model under consideration;

$$
B I C=-2 \log (L)+\mathrm{k} \ln (n),
$$

where $\mathrm{k}$ is the number of parameters in the model, $\mathrm{L}$ is maximum probability function for the model under consideration and $\mathrm{n}$ is the number of data points.
RMSD of the model in terms of parameters is defined as square root of mean square error.

To calculate the criteria for choosing an optimal model, the software program 'Companing models' was used (MAVREVSKI, 2014).

\section{Results}

Values of the determined dendrobiometrical indicators are shown in Table 2 .

\begin{tabular}{|c|c|c|c|c|c|c|c|c|}
\hline $\begin{array}{c}\text { Sample } \\
\text { plot }\end{array}$ & $\begin{array}{l}\text { Composition } \\
\text { (by volume } \\
\text { percentage) }\end{array}$ & $\begin{array}{c}\text { Studied } \\
\text { trees }\end{array}$ & $\begin{array}{c}D B H_{\mathrm{m}} \\
(\mathrm{cm})\end{array}$ & $\begin{array}{l}H_{\mathrm{m}} \\
(\mathrm{m})\end{array}$ & $\begin{array}{l}L_{\mathrm{km}} \\
(\mathrm{m})\end{array}$ & $\begin{array}{c}\sum G \\
\left(\mathrm{~m}^{2}\right)\end{array}$ & $\begin{array}{c}V \text { stem } \\
\left(\mathrm{m}^{3}\right)\end{array}$ & $\begin{array}{c}V \text { with } \\
\text { branches } \\
\left(\mathrm{m}^{3}\right)\end{array}$ \\
\hline \multirow{2}{*}{ SP1 } & $\begin{array}{c}\text { F. sylvatica } \\
(99.9 \%)\end{array}$ & 218 & 15.2 & 18.9 & 4.9 & 3.9757 & 44.21 & 50.04 \\
\hline & $\begin{array}{c}\text { P. abies } \\
(0.1 \%)\end{array}$ & 2 & 8.4 & 5.3 & 3.5 & 0.0111 & 0.04 & 0.06 \\
\hline Total & & 220 & & & & 3.9868 & 42.25 & 50.10 \\
\hline \multirow{2}{*}{ SP2 } & $\begin{array}{c}\text { F. sylvatica } \\
(97.4 \%)\end{array}$ & 66 & 19.1 & 20.6 & 8.4 & 1.8838 & 21.94 & 26.00 \\
\hline & $\begin{array}{c}\text { P. abies } \\
(2.6 \%)\end{array}$ & 3 & 16.9 & 17.5 & 5.4 & 0.0673 & 0.62 & 0.69 \\
\hline Total & & 69 & & & & 1.9511 & 22.56 & 26.69 \\
\hline
\end{tabular}

Table 2. Dendrobiometrical characteristics

$D B H_{\mathrm{m}}$, mean diameter; $H_{\mathrm{m}}$, stand mean height; $L_{\mathrm{km}}$, arithmetic mean lengths of crown; $\sum G$, total basal area; $V$ stem, volume of the stem; $V$ with branches, volume of the trees with branches.

Mean values of dendrometric indicators in SP1 are lower, but the total circular area and volumes (without and with branches) are higher due to the higher number of trees in the sample plot.

The established values of average tree height, combined with age (Table 1) classify studied forest stands to productivity class II (SP1) and I (SP2), respectively (NEDYALKOv, 2004). The control plot is of a lower class, but the number of trees offsets the volume, and the productivity of the thinned plot increased due to the 'opening' of the stand.

The multiple linear regressions applied to study the dynamics of dendrobiometrical indicators (DBH, $\mathrm{H}$ and $\mathrm{L}_{\mathrm{k}}$ ) over the aboveground volume (Model 1 for SP2 and Model 2 for SP1) is shown in Table 3.

It resulted in the following regression equations for the relationship between dendrobiometrical indicators. For SP1:

$$
\mathrm{V}=-0.199-0.030 . D B H-0.04 \cdot H+0.006 \cdot L_{k}
$$
and for SP2 :

$$
\mathrm{V}=-0.385+0.037 \cdot \mathrm{DBH}+0.003 \cdot L_{k} \text {. }
$$

There is a requirement for multiple regression factor variables to be independent from each other, if not - there is multicollinearity and in its presence, the estimated regression coefficients are inefficient and unreliable (Dimitrov, 2003). To establish the multicollineari- ty, correlation matrix factor variables were investigated.

When constructing the matrix, with respect to the dependence between the height of the trees on one hand and the respective crowns lengths on the other, is the presence of the dependence, in both cases, where the Pearson's correlation coefficient is higher than 0.7 (0.804 and 0.712 respectively for SP2 and SP1). In the control plot (SP1), the above fact was also found valid with respect to the dependence between the diameter and the height (Pearson's correlation coefficient 0.713). These values are close to the limit and because the relationship between the variables is not functional, but correlational, an incomplete multicollinearity expected to occur (in which the defining variables are approximately linearly dependent)(Dimitrov, 2003). Moreover, according to KHEDI and Dillon (1965), when the coefficients of correlation between the interacting factor variables are under 850 , full multicollinearity is out of discussion.

The stepwise multiple regression was realized to avoid the negative impact of multicollinearity (Table 3, Models 3, 4, 5 and 6).

Model 3 was obtained for SP2, where only the influence of the DBH over the stock was investigated. The last three models, referred to SP1, show the relationship between the DBH (Model 4); of DBH, together 
Table 3. Multiple regression of diameter, height, and biometric parameters of crowns influence on F. sylvatica

\begin{tabular}{|c|c|c|c|c|c|c|c|c|}
\hline $\begin{array}{l}\text { Sample } \\
\text { Plot }\end{array}$ & Factors & $R$ & $R^{2}$ & $S_{\mathrm{y}}$ & $\begin{array}{c}\text { Regression } \\
\text { coefficients } \\
\text { (b0, b1, } \\
\text { b2....bn) }\end{array}$ & Beta & $T$ & Sig. $t$ \\
\hline \multirow{5}{*}{ 1) $\mathrm{SP} 2$} & & 0.980 & 0.960 & 0.037 & & & & \\
\hline & $\begin{array}{l}\text { Constant } \\
\text { (a) }\end{array}$ & & & & -0.385 & & -8.757 & 0.000 \\
\hline & $\mathrm{DBH}$ & & & & 0.037 & 0.952 & 27.246 & 0.000 \\
\hline & $H$ & & & & 0.000 & 0.030 & 0.064 & 0.949 \\
\hline & $L_{\mathrm{k}}$ & & & & 0.003 & 0.410 & 0.956 & 0.343 \\
\hline \multirow{5}{*}{ 2) $\mathrm{SP} 1$} & & 0.971 & 0.944 & 0.035 & & & & \\
\hline & $\begin{array}{l}\text { Constant } \\
\text { (a) }\end{array}$ & & & & -0.199 & & -16.181 & 0.000 \\
\hline & $\mathrm{DBH}$ & & & & -0.030 & 0.986 & 42.276 & 0.000 \\
\hline & $H$ & & & & -0.040 & -0.090 & -3.273 & 0.010 \\
\hline & $L_{\mathrm{k}}$ & & & & 0.006 & 0.082 & 3.540 & 0.000 \\
\hline \multirow{3}{*}{ 3) $\mathrm{SP} 2$} & & 0.979 & 0.959 & 0.037 & & & & \\
\hline & $\begin{array}{l}\text { Constant } \\
\text { (a) }\end{array}$ & & & & -0.378 & & -19.984 & 0.000 \\
\hline & $\mathrm{DBH}$ & & & & 0.038 & 0.979 & 38.698 & 0.000 \\
\hline \multirow{3}{*}{ 4) SP1 } & & 0.969 & 0.940 & 0.036 & & & & \\
\hline & Constant(a) & & & & -0.225 & & -28.871 & 0.000 \\
\hline & $\mathrm{DBH}$ & & & & 0.031 & 1.068 & 57.925 & 0.000 \\
\hline \multirow{4}{*}{ 5) $\mathrm{SP} 1$} & & 0.970 & 0.941 & 0.036 & & & & \\
\hline & $\begin{array}{c}\text { Constant } \\
\text { (a) }\end{array}$ & & & & -0.230 & & -28.451 & 0.000 \\
\hline & $\mathrm{DBH}$ & & & & 0.029 & 0.946 & 46.882 & 0.000 \\
\hline & $L_{\mathrm{k}}$ & & & & 0.003 & 0.042 & 2.078 & 0.039 \\
\hline \multirow{5}{*}{ 6) SP1 } & & 0.971 & 0.944 & 0.035 & & & & \\
\hline & Constant(a) & & & & -0.199 & & -16.181 & 0.000 \\
\hline & $\mathrm{DBH}$ & & & & 0.030 & 0.986 & 42.276 & 0.000 \\
\hline & $L_{\mathrm{k}}$ & & & & 0.006 & 0.082 & 3.540 & 0.000 \\
\hline & $H$ & & & & -0.004 & -0.090 & -3.273 & 0.001 \\
\hline
\end{tabular}

$R$, correlation coefficient; $R^{2}$, coefficient of determination; $S_{y}$, standard error of estimates; Beta, standardized coefficient; $t$, Student's criteria; Sig., level of significance.

Table 4. Correlation matrix for multicollinearity examination

\begin{tabular}{|c|c|c|c|c|c|c|c|}
\hline & $\begin{array}{c}\text { Factor } \\
\text { variables }\end{array}$ & $D B H / \mathrm{SP} 2$ & $H / \mathrm{SP} 2 \mathrm{t}$ & $L_{\mathrm{k}} / \mathrm{SP} 2$ & $D B H / \mathrm{SP} 1$ & $H / \mathrm{SP} 1$ & $L_{\mathrm{k}} / \mathrm{SP} 1$ \\
\hline \multirow{3}{*}{$D B H / \mathrm{SP} 2$} & $\begin{array}{c}\text { Pearson } \\
\text { correlation }\end{array}$ & 1.000 & $0.680 * *$ & $0.612^{* *}$ & 1.000 & $0.713 * *$ & $0.567 * *$ \\
\hline & Sig. (2-tailed) & & 0.000 & 0.000 & & 0.000 & 0.000 \\
\hline & $\mathrm{N}$ & 66 & 66 & 66 & 218 & 218 & 218 \\
\hline \multirow{3}{*}{$H / \mathrm{SP} 2$} & $\begin{array}{l}\text { Pearson } \\
\text { correlation }\end{array}$ & $0.680 * *$ & 1.000 & $0.804 * *$ & $0.713 * *$ & 1.000 & $0.712 * *$ \\
\hline & Sig. (2-tailed) & 0.000 & & 0.000 & 0.000 & & 0.000 \\
\hline & $\mathrm{N}$ & 66 & 66 & 66 & 218 & 218 & 218 \\
\hline \multirow{3}{*}{$L_{\mathrm{k}} / \mathrm{SP} 2$} & $\begin{array}{l}\text { Pearson } \\
\text { correlation }\end{array}$ & $0.612 * *$ & $0.804 * *$ & 1.000 & $0.567 * *$ & $0.712 * *$ & 1.000 \\
\hline & Sig. (2-tailed) & 0.000 & 0.000 & & 0.000 & 0.000 & \\
\hline & $\mathrm{N}$ & 66 & 66 & 66 & 218 & 218 & 218 \\
\hline
\end{tabular}

**Correlation is significant at the 0.01 level (2-tailed). $\mathrm{N}$, number of the studied trees. 


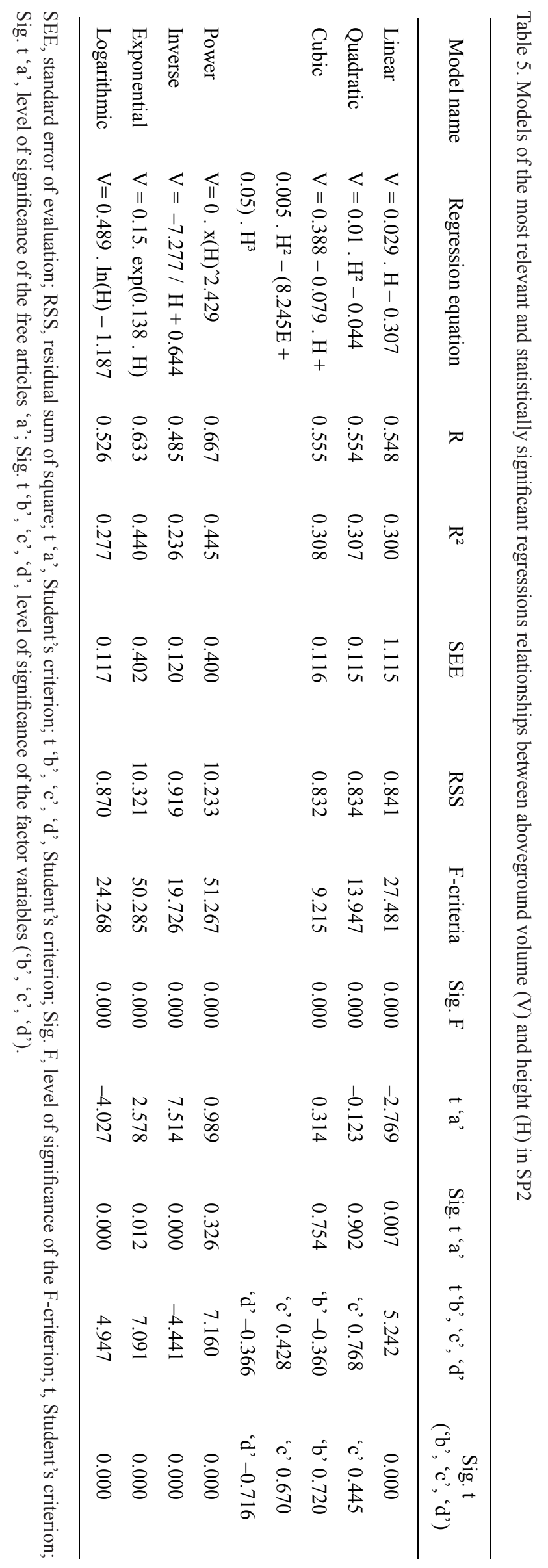


with crown length $\left(\mathrm{L}_{\mathrm{k}}\right)$ - Model 5 and $\mathrm{DBH}$, together with the length of crowns $\left(\mathrm{L}_{\mathrm{k}}\right)$ and height $(\mathrm{H})-$ Model 6 on the volume.

With the statistically significant coefficients determined by the analysis, there may be proposed the following regression equations for determining the aboveground volume through all other surveyed dendrobiometrical indicators in the studied beech forests (Table 3, Model 6 and 3). For SP1:

$$
\begin{gathered}
\mathrm{V}=-0.225+0.031 \cdot D B H \\
\mathrm{~V}=-0.230+0.029 \cdot D B H+0.003 \cdot L_{k}, \\
\mathrm{~V}=-0.199+0.030 \cdot D B H+0.06 \cdot L_{k}-0.04 \cdot H . \\
\text { For SP2: } \\
\quad \mathrm{V}=-0.378+0.038 \cdot D B H .
\end{gathered}
$$

The height and DBH are the major factors in the basic equation for calculating the volume. The statistical analysis and the resulting model did not prove the influence of height on the volume in SP2. Therefore, the need to seek other options for establishing this relation was considered. These two factors ( $H$ and $V$ ) were linked by applying descriptive statistics and testing of one linear and 6 non-linear regression equations (quadratic, cubic, power, inverse (hyperbolic), exponential and logarithmic), Table 5.

The power model $\left(y=a x^{b}\right)$ was unimportant due to the zero regression coefficient ' $a$ '. The quadratic and cubic models were excluded because their regression coefficients were higher than the significance level (0.05).

Therefore, the optimal model for representing the relationship under consideration is linear, inverse, exponential and logarithmic. Which model to choose is decided by applying the criteria for choosing the optimal model (AIC, BIC and RMSD), Table 6.

Table 6. Calculation of the criteria for choosing an optimal regression model between aboveground volume (V) and height (H) in SP2 through the program 'Comparin models'

\begin{tabular}{ccccccc}
\hline Regression model & $\mathrm{SS}$ & $\mathrm{K}$ & $\mathrm{N}$ & $\mathrm{AIC}$ & $\mathrm{BIC}$ & $\mathrm{RMSD}$ \\
\hline Linear & 0.841 & 2 & 66 & -341.13772 & -275.37705 & 0.11463 \\
Inverse (hyperbolic) & 0.919 & 2 & 66 & -275.70508 & -269.52321 & 0.11983 \\
Exponential & 10.321 & 2 & 66 & -116.07419 & -109.89233 & 0.40158 \\
Logarithmic & 0.870 & 2 & 66 & -279.32141 & -273.13955 & 0.11659 \\
Reference value & & & & min & min & min \\
\hline
\end{tabular}

RSS, residual sum of square; K, number of parameters in the model; N, number of data points.

According to the criterion AIC, BIC and RMSD (Table 6), the optimal model of the relationship between $\mathrm{V}$ and $\mathrm{H}_{\mathrm{m}}$ is the linear of the type:

$$
\mathrm{Y}=\mathrm{ax}+\mathrm{b} \text {. }
$$

After testing, there were determined the following model parameters for the dependence (Table 5):

$$
\mathrm{V}=0.029 H-0.307 \text {, }
$$

$\mathrm{Y}(\mathrm{V})$ - aboveground volume of the stand, $\mathrm{m}^{3} ; \mathrm{x}(\mathrm{H})-$ stand height, $\mathrm{m} ; a$ and $b$ - regression coefficients.

\section{Discussion}

It is well known that in forest dendrobiocenoses the relationship between dendrobiometrical indicators is relatively complex and varied, and almost never this relationship can be expressed and appreciated if considered separately.

In the two studied plots, the connection between dendrometrical indicators for the beech trees predominant in the stand composition were examined (Table 2). The regression equations (Table 3, Model 1 and 2) showed the general relationship between the aboveground volume and the factor variables. SP1 needed stand height $(\mathrm{H})$, DBH and length of crown $\left(\mathrm{L}_{\mathrm{k}}\right)$ to calculate aboveground volume. Volume $(\mathrm{V})$ was dependent on each of the other variables, but in this case, $\mathrm{H}$ has a greater weight. In contrast, in SP2, height did not participate in the regression equation determining the aboveground volume. This fact is a surprise, as height is a major volume forming factor in the basic equation for volume calculation. On the other hand, high values of correlation coefficient $R>0.3$ on both plots $(0.971$ SP1 and 0.980 SP2) and $R^{2}$ values ( 0.944 and 0.960 for SP1 and SP2, respectively) show that the dependence between the studied variables is strong and their variations reflect the variations in the stand volume (more valid for SP2 - within 96\%).

Despite the results and analysis do not imply so far a serious danger of multicollinearity occurrence, the presence of incomplete multicollinearity required to apply a stepwise multiple regression. The stepwise multiple regression used to avoid the negative impact of multicollinearity (Table 3, Models 3, 4, 5 and 6) was applied, where the factor dependent variables were excluded from the regression equation as negligible. In our opinion, the studied relationships are better characterised with the new regression equations obtained 
after application of stepwise multiple regression with participation of some or all the dendrometric indicators studied (Table 3, Models 3, 4, 5 and 6).

The analysis of the regression equations obtained shows that in most cases (except for the last equation SP1), the signs of regression coefficients are in accordance with the logic of their influence and role on the stock, i.e. with increasing factor variables studied - increases the volume. What do these coefficients do?

For SP1 - increasing DBH with $1 \mathrm{~cm}$, and in eliminating the influence of $\mathrm{Lk}$ and $\mathrm{H}$, the volume of the stems of standing trees has been growing with 0.031 $\mathrm{m}^{3}, 0.029 \mathrm{~m}^{3}$ and $0.030 \mathrm{~m}^{3}$ respectively. For SP2 the increase is almost identical (with $0.038 \mathrm{~m}^{3}$ ).

The correlation coefficients $(R)$ between the relevant factors and stock in both cases are high and in a narrow range (from 0.969 to 0.979 ), indicating a strong two-way link $-R^{2}$ (from 0.940 to 0.959 ), which is more valid for SP2. This confirms the importance of the amendment of these taxonomy parameters on volume variation.

The null hypothesis has been rejected, and the models have been detected statistically significant, since in the performed ANOVA, Fisher's coefficients F (SP2, Model 3) =1,497.523; F (SP1, Model 4) = 3,355.261; $\mathrm{F}(\mathrm{SP} 1$, Model 5) $=1,705.656$ and $\mathrm{F}(\mathrm{SP} 1$, Model 6$)=$ $1,191.998$, at Sig. $\mathrm{F}=0.000<0.05$ (significance level) for both experimental plots (in all four models) and degrees of freedom $d f=3$. This was also confirmed by the Bartlett's test of Sphericity in which for both plots Sig. $=0.000<0.05$, i.e., the cloud data have some 'roundness' and they do not lie on a line in the space. In the conducted KMO test (Kaiser-Meyer-Olkin Measure of Sampling Adequacy) the result is $\geq 0.5$ (0.703 to 0.674 for SP2 and SP1, respectively), which is an indication of multi-dimensional distribution of the data close to normal.

Table 3 shows that statistically significant regression coefficients are those related to the free member of the equation, as well as any other factor variables. This is evident from the values of functions' free members (constants - 'a') and from regression coefficients ' $b$ ' and their corresponding values of the Student's 't-criterion and the level of significance (Sig.t) which proves that this regression coefficient does not differ statistically from 0 .

Slightly stronger influence of the diameter in SP1, assessed by the higher values of its standardized coefficient (Beta) (from 0.946 to 1.068) has been found. The standard error values are close to $0\left(S_{\mathrm{y}}\right.$ is from 0.035 to 0.037), expressing high precision calculations.

In SP1, the aboveground volume size depends on three measurable indicators (variables) with different participation in the three models presented. In SP2 the height (as a factor) does not participate in the regression equation (Table 3, Model 3). There has been stated that ignoring height as the main volume factor is unacceptable. Therefore, further testing of models illustrating the relationship between the aboveground volume and the stand height $(\mathrm{H})$ in SP2 was necessary.

Separately, all three criteria used (AIC, BIC and RMSD) are only sensitive to the number of parameters, but they are not sensitive to the functional form of the model. Comparison of models with AIC and BIC was performed because the residual sum of squares is directly available in the SPSS software product used. On the other hand, RMSD method could not handle cases with small sample sizes and a large number of parameters in the models, as this could lead to negative square roots. In addition, there is no statistical justification for RMSD. For this reason, it is necessary to evaluate the models by combining the three criteria for assessing the 'optimality' of the models. Through the 'Comparing Models' module, these criteria were computed and compared. The formulas used in the 'Comparing Models' for calculating these criterions are (MAVREVSKI, 2012): $\mathrm{AIC}=n \ln (R S S / n)+2 k$, when $n / k \geq 40$,

$$
\begin{gathered}
\mathrm{AIC}=n \ln (R S S / n)+2 k+(2 k(k+1) /(n-k-1)), \\
\text { when } n / k<40, \\
\mathrm{BIC}=n \ln (R S S / n)+k \ln (n),
\end{gathered}
$$

where $n$ is the number of data points; $k$ is the number of parameters fit by the regression plus one (since regression is 'an estimating ' of the sum-ofsquares, as well as the values of the parameters); RSS, or sum of square error, is the sum of the squares of the vertical deviations from each data point to the fitted line.

$$
\mathrm{RMSD}=\sqrt{ } R S S / n-k,
$$

where $\mathrm{n}$ is the number of data points; $\mathrm{k}$ is the number of parameters; RSS is the sum of square error.

Regression with lower AIC, BIC, and RMSD values is considered to be better.

In the selected 'optimal' linear regression for SP2 (Table 5 and 6), the dependent height (V) is viewed according by one factor (stand height $-\mathrm{H}$ ). The correlation coefficient $\mathrm{R}=0.548$ and the determination coefficient $\mathrm{R}^{2}=0.300$. When the coefficient $\mathrm{R}$ is in the range of 0.3 to 0.7 , the relationship is medium in intensity and the value of $\mathrm{R}^{2}$ indicates that the degree of dependence between the studied factors variables is $30 \%$. The presented linear regression satisfactorily represents the relationship under consideration, which is evident from the Fischer's coefficient $(\mathrm{F}=27.471)$ and its corresponding significance level (Sig. $F=0.000$ ) lower than the error $\alpha=0.05$. The model itself is adequate, according to Student's ' $\mathrm{t}$ '-criterion $(\mathrm{t}=-2.769)$ and its significance level (Sig. $t=0.007<0.05$ ), in addition the free member of the model is statistically significant, too. This also applies to the regression coefficient before the factor variable $(\mathrm{H})$, where $\mathrm{t}=5.242$ and $\mathrm{Sig}$ $\mathrm{t}=0.000$. Relatively close to $0(\mathrm{Sy}=0.115)$ value of the standard error of the estimate is an expression for acceptable accuracy of the relationship under consideration. The regression is positive, which is visible from the sign before the regression coefficient. The value of this coefficient indicates that the change in stem height 
by $1 \mathrm{~m}$ is expected to change the aboveground volume by $0.029 \mathrm{~m}^{3}$ on average. Therefore, we have a reason to conclude that there exists regression relationship between the aboveground volume and stand height $(\mathrm{H})$ in SP2, according to the represented linear model.

\section{Conclusions}

The results of the statistical analysis demonstrated the effectiveness of the applied linear regression analysis. It showed that the link between stand volume and established average diameter, average height and length of the crowns in the studied beech stands is strong twoway.

The finding results showed that dendrobiometrical measurements give better inventory characteristics for SP2.

The conducted tests - Barlett and KMO, showed that the 'cloud' data show some 'sphericity', they do not lie on a line in the space and have distribution close to normal.

There is evident presence of incomplete multicollinearity due to the links between aboveground volume and height in one case, and between aboveground volume and length of the crowns in the second (SP1). After application of a stepwise multiple regression, more accurate regression equations have been proposed to estimate the volume for studied plots.

An optimal mathematical model linear for the relationship between stock and average height in one of the sample plots is proposed, based on the AIC, BIC and RMSD criteria for the selection of an 'optimal' model from different model classes.

The proposed equations allow determining the volume of forest stand of native beech by diameter, height and length of the crown or just by measuring some of them in the studied and similar stands.

\section{Acknowledgements}

The work is a part of the project 'Land-use and management impacts on carbon sequestration in mountain ecosystems ' funded within the framework of the BulgarianSwiss Research Programme (BSRP), 2011-2016.

\section{References}

AKaIKE, H., 1974. A new look at the statistical model identification. IEEE Transactions on Automatic Control, 19: 716-723.

BartelinK, H.H., 1997. Allometric relationships for biomass and leaf area of beech (Fagus sylvatica L.). Annales des Sciences Forestières, 54: 39-50.

CBNPMP (Central Balkan National Park Management Plan 2001-2010), 2001. Sofia: Central Balkan
National Park Directorate, Ministry of Environment and Waters, Republic of Bulgaria. 319 p. [cit. 2017 02-13]. http://visitcentralbalkan.net/assets/userfiles/ file/Administration/CBNP\%20MP-eng2.pdf

Dimitrov, E., Lazarov, E., 1979. Matematicheski model na zavisimostta mezhdu stablenya zapas i visochinata, izrazeni v nyakoi mestni opitni tablitsi za visokostableni darvesni vidove [Mathematical model of dependence between stem stock and height expressed in some local experimental tables for high stem wood species]. Gorskostopanska Nauka, 2: 23-33.

Dimitrov, E., 2003. Modelirane na stroezha, obema $i$ sortimentite na srednovazrastnite $i$ dozryavashchtite belborovi, smarchovi $i$ elovi dendrotsenozi [Modeling of structure, volume and assortments of moderate-age and sub-mature dendrocoenoses of Scots Pine, Norway Spruce and Silver Fir]. Sofia: Simolini 94. 159 p.

Evangelov, E., Poryazov, YA., Dobrichov I., Tonchev, T., 2004. Opredelyane na vidovite visochini na visokostablen buk [Determining the form heights high productive beech]. In Evangelov, E., Poryazov, YA., Dobrichov, I., Tonchev, T. (eds). Narachnik na taksatora. Sofia: Bulvark, p. 410-411.

FORSTREUTER, M.,1999. Ergebnisbericht: Ökologie der Gehölze [Report: Woodland Ecology]. Report SS99. Berlin: Technische Universität, Institut für Ökologie und Biologie. 22 p.

GUERICKE, M., 2001. Growth dynamics of mixed stands of beech and European larch. Technical report, Fakultät für Forstwissenschaften und Waldökologie. Göttingen: Georg-August Universität. 220 p.

Khedi, E., Dillon, D., 1965. Proizvodstvennye funktsii $v$ selskom khoziaistve [Production functions in agriculture]. Moscow: Progress Publ. 588 p.

KrAmer, H., 1982. Kurzfristige Zuwachsreaktionen bei Buche in Abhängigkeit von Witterung und verschiedenen Baummerkmalen. Allgemeine Forstund Jagdzeitung, 153: 57.

KindermanN, G.E., 1998. Die Flächenanteile der Baumarten [The tree species area]. Diploma work. Perchtolsdorf, Deutschland: Universität für Bodenkultur, Institut für Waldwachstumsforschung. $46 \mathrm{p}$.

Kullback, S., Leibler, R.A., 1951. On information and sufficiency. Annals of Mathematical Statistics, 22: 79-86.

MavrevsKI, R., 2012. Modelirane $i$ optimizatsya pri medico-biologichni izsledvanya [Modeling and optimization at medical-biological studies]. PhD thesis. Blagoevgrad: Centre for Advanced Bioinformatics Research of the South-West University. $140 \mathrm{p}$.

MAVREVSKI, R., 2014. Selection and comparison of regression models: estimation of torque-angle relationships. Comptes Rendus De l'Academie Bulgare Des Sciences, 67 (10): 1345-1354.

Mihov, I., Lazarov, E., 1979. Modeli na opitnite ta- 
blitsi za chirikolostnite darvesni vidove [Models of yield tables for broadleaved tree species]. Gorsko Stopanstvo, 3: 19-20.

Myung, I.J., 2000. The importance of complexity in model selection. Journal of Mathematical Psychology, 44: 190-204.

Naydenova, L., Ferezliev, A., Zhiyanski, M., 2015. Carbon stocks in components of natural European beech ecosystems after thinning activities in Central Balkan. In Forestry: bridge to the future: 90 years higher forestry education in Bulgaria. Book of abstracts. Sofia: Publishing house of the University of Forestry, p. 83.

Nedyalkov, S., 2004. Opredeliane na boniteta na visokostableni nasazhdenia ot buk [Determine the site index of tall beech trees]. In Evangelov, E., Poryazov, YA, Dobrichov, I., Tonchev, T. (eds). Narachnik na taksatora. Sofia: Bulvark, p. 151.

NimH, 2017. National Institute of Meteorology and Hydrology of the Bulgarian Academy of Sciences data files.

SchwARZ, G., 1978. Estimating the dimension of a model. Annals of Statistics, 6: 461-464.

Sirakov, G., Duhovnikov, Y., 2004. Opredelyane na protsenta na klonite $\mathrm{v}$ zavisimost ot dalzhinata na koronata $\mathrm{v}$ protsent ot srednata visochina [Determining the percentage of branches depending on the length of the crown as a percentage of average height]. In Krastanov, K., Raikov, R. (eds). Spravochnik po dendrobiometrya. Sofia: Bulprophor Publishing House, p. 619.

Tonchev, T., Dimitrova, V., Dimitrov, M., Mihov, I., 2012. Investigation of the aboveground phytomass and annual growth of beech forests in Bulgaria. Forestry Ideas, 18 (2) (44): 196-202.
Tsakov, H., Stoykov, H., Hristova, H., 2003. Dinamika na rastezhnite pokazateli na estestveni bukovi nasazhdenya nablyudavani v Sredna Stara planina [Dynamics of the growth indicators of natural beech stands observed in Central Balkan Mountains]. In Sbornik nauchni dokladi ot Mezhdunarodna nauchna konferentsia '50 godini Lesotehnicheski universitet'. Sofia: IK pri LTU, p. 120-122.

Vasileva, S., Stipcov, V., 2012. Possibility for close to nature management of beech forests of Teteven Municipality. Management and Sustainable Development, 3: 34 .

Widlowski, M.V., Pinty, B., Gorbon, N., 2003. Allometric relationships of selected European tree species: parametrizations of tree architecture for purpose of 3-D canopy reflectance models used in the interpretation of remote sensing data: Betula pubescens, Fagus sylvatica, Larix deciduas, Picea abies, Pinus sylvestris. Luxembourg: Office for Official Publications of the European Communities. $61 \mathrm{p}$.

ZhiYANSKi, M., Ferezliev, A., Sokolovska, M., 2014. Harakteristiki na nadzemnata biomasa i vagleroden zapas $\mathrm{v}$ komponenti na ekosistema, formirana sled zalesyavane s byal bor v raiona na Severozapadni Rodopi [Characterization of above ground biomass and carbon stock in components of ecosystem formed after afforestation with scots pine in the region of Northwestern Rhodopes]. In Sbornik s nauchni publikacii na Instituta za gorata '145 godini BAN'. Sofia: IG - BAN, p. 224-238.

Received June 5, 2017 Accepted November 30, 2017 